Myth, Land, and History in the Poetry

of James Clarence Mangan and Ernest Jones 


\section{Myth, Land, and History in the Poetry of James Clarence Mangan}

\section{And Ernest Jones}

Much of the radical political poetry of the eighteen forties was steeped in mythic representations of history and the land. The attainment of an equitable future appeared predicated on the successful invocation of a past 'Golden Age', a realignment of the land and the landscape to a mythic vision. One of the functions of poetry within radical political movements was to mythopoeically embody the ethos of the oppressed community, and to present that community as a body worthy, through its cultural sophistication, of selfdetermination. It is no accident that Chartism's eventual de facto leader, Ernest Charles Jones (1819-69), was an admired and prolific poet, or that he and Feargus O'Connor (1794-1855) founded a journal companion piece to the Northern Star Chartist newspaper entitled the Labourer in 1847 , which intended to place 'poetry and romance side by side with politics and history'. ${ }^{1}$ At the same time as Irish poets including Thomas Davis (1814-45), John de Jean Frazer (?1804-52), and James Clarence Mangan (1803-49) were helping to forge a new Irish cultural identity in support of Irish nationalism, Chartist poets including Jones were attempting a similar project for a radical British working-class readership. This article undertakes a comparative study of the poetry of Mangan and Jones (both of whom found a new political consciousness in 1846), and finds the points where they converge and differ to be equally illuminating in terms of their mythic representations of the land and the past. Moreover, this study reveals a tentative discourse between Irish nationalism and Chartism expressed through the medium of political poetry.

By 1848 James Clarence Mangan and Ernest Jones were the most admired poetic exponents of their respective political affiliations. These radical movements, Chartism and Irish nationalism, simultaneously confronted a beleaguered London government reeling from the implications of widespread industrial unrest, the horrific consequences of the Irish 
Famine, and the reverberations of democratic revolutions erupting across mainland Europe. Both Chartists and Irish nationalists were to feel the weight of government action in the wake of popular agitation in favour of their causes. Jones was imprisoned for two years for seditious speech-making in June 1848, just one month after the major Irish nationalist figure John Mitchel (1815-75) was tried and transported under similar charges, while Mangan died of causes including malnutrition in June 1849, during a period in which The Nation, which had published some of his later work, was being suppressed by the government.

The effect of radicalization on the poetry of both men was transformative. Prior to 1846, Mangan's poetry had been largely published in the nominally Unionist Dublin University Magazine. He was politicized by the effects of the Irish Famine, while Jones's sudden immersion in Chartist politics in 1846 was a more mysterious process, especially given his gentry background. When Jones's early poetry did touch on politics, it reflected a generally Tory outlook: his pre-Chartist work appeared in conservative London publications including the Court Journal and the Morning Post. Mangan's nostalgic visions of a mythic historical Ireland (sometimes allegorized through loose ‘translations' from European poetry) became much more intensely focused after 1846: as Robert Welch observes, his more overtly nationalist poetry exhibited 'more personal fire and anger', though it was still 'distanced by the consistent use of mask and metaphor'. ${ }^{2}$ Jones's political transformation was more demonstrably dramatic, but his poetry retained the influences of British and German Romanticism; the latter absorbed during his upbringing as the son of the equerry to the Duke of Cumberland (1771-1851, from 1837 King Ernest Augustus of Hanover) in the Duchy of Holstein. In their different ways Jones and Mangan became poetic spokesmen for their causes once they entered into the field of explicitly radical poetry.

It was politically expedient for the Chartist movement to cast Ernest Jones as previously apolitical when he rapidly emerged as an influential orator and poet in 1846 . In 
fact, in a three-poem series entitled 'Echoes' which he published in the Morning Post in early 1844 Jones consecutively addressed the problems of Ireland, urban industrialization, and political agitation in rural Britain. The first poem of the series, 'The Golden Harp', ${ }^{3}$ which is absent from existing Jones bibliographies, is Jones's interpretation of the events of 1843, 'the Repeal Year', when some observers feared that increased political activity and agitation in Ireland had brought Britain close to civil war. ${ }^{4}$ The poem celebrates the withdrawal of the threat of violence, but in terms of the contemporary issues affecting Ireland it is difficult to tell where the writer's political sympathies lie. This ambiguity is less a deliberate obfuscation than a result of the confusing use of multiple metaphors and imagery which Jones uses to approach his difficult subject. To be generous to Jones it could be suggested that the poem's confusion reflects the general strategic uncertainty of Britain's approach to Ireland. In the poem 'a beautiful Spirit' (1.2) plays a 'golden harp' (1.14) in response to a thunderous storm in which are heard the shouts of millions, 'like the cry of a nation's despair' (1.13). This music has the effect of waking the people 'from their sleep of long years' (1.20), but there is no echo, a lack of response occasioned apparently by a lack of leadership: 'That coward heart shrunk at the storm it had called, / And the legions they doubt, for the leader's appalled!' (11.28-9). The tempest passes and the beautiful Spirit is left to quench the flames caused by the lightning's blasts with her tears. She then gazes on a dull flower, identified as a shamrock, who declares that after the defeat of treachery 'the spirit of ERIN shall summon again / From her golden lyre a golden strain' (11. 55-6). The shamrock then closes the poem with a pair of aphoristic couplets of a distinctly anti-revolutionary nature:

The sun shines but when tempests cease,

Freedom only lives in Peace.

It is not discord, fear, and ire

Can raise the flower or wake the lyre. (11.57-60) 
The problem with this poem, apart from liberal use of national and poetic clichés, is that the reader barely has time to establish the symbolic nature of one metaphor before another comes along to confuse the picture. The tempest is clearly emblematic of revolutionary fervour, but it is difficult to ascertain with any degree of certainty what the other images are intended to refer to. If the 'coward heart' is meant to represent Daniel O'Connell, the leader of the Repeal Association, or perhaps the leaders of the Young Ireland movement, it is still difficult to determine whether the voice of the poet is speaking on behalf of the oppressed of Ireland, or crowing over the failure of nerve of an attempted insurrection. 'The Golden Harp' is important, however, in that it establishes Jones's early engagement with political issues, and indeed Irish political issues, almost two years before his involvement with Chartism, and highlights Ireland as an important subtext with regards to poetic responses to wider political agitation throughout Britain.

Mangan's poetry prior to his eventual radicalization in 1846 is less politically naïve or confused than some of Jones's of the same period (it should be noted that Mangan was sixteen years older), but where its subjects pertain to Ireland as a nation they are treated more with sentimental regret than with political resolve. The emphasis in much of Mangan's early work is on a retreat into a mythical past that deflects political realities rather than confronts them. One of his most celebrated earlier poems is 'Kathaleen Ny-Houlahan' (1841), ${ }^{5}$ a loose translation from an original Gaelic lyric dating from the Jacobite rebellions of first half of the eighteenth century:

Long they pine in weary woe, the nobles of our land,

Long they wander to and fro, proscribed, alas! and banned;

Feastless, houseless, altarless, they bear the exile's brand, But their hope is in the coming-to of Kathaleen Ny-Houlahan! 
Think her not a ghastly hag, too hideous to be seen,

Call her not unseemly names, our matchless Kathaleen:

Young she is, and fair she is, and would be crowned a queen,

Were the king's son at home here with Kathaleen Ny-Houlahan! (11.1-8)

As Henry J. Donaghy has observed, 'the poem looks to Kathaleen's deliverance but, like most of the Jacobite poems, without a great deal of optimism' ${ }^{6}$ The last two stanzas of the poem appear to abrogate political responsibility for the situation in Ireland, appealing to the Biblical divinity and falling back on the Israelite analogy common to many oppressed peoples:

Let us pray to Him who holds Life's issues in His hands -

Him who formed the mighty globe, with all its thousand lands;

Girding them with seas and mountains, rivers deep, and strands, To cast a look of pity upon Kathaleen Ny-Houlahan!

He, who over sands and waves led Israel along He, who fed, with heavenly bread, that chosen tribe and throng He, who stood by Moses, when his foes were fierce and strong May He show forth His might in saving Kathaleen Ny-Houlahan. (11.13-20)

In terms of the identification of any political solution the emphasis at the conclusion of this poem is on prayer rather than action: Kathaleen Ny-Houlahan, the mythic personification of Ireland, inspires pity and regret rather than anger or resolve. The well-modulated emotional integrity of this poem combined with its lack of recognition of any real form of political agency bears comparison with 'The Cornfield and the Factory', ${ }^{7}$ the second part of Jones's pre-Chartist poem sequence, 'Echoes'. Jones's poem is similarly expressive in its emotional 
engagement with its subject of the degrading effects of urban industrialization - to the extent that it was re-published as a 'Chartist' poem in the Northern Star in 1846 - but its primary function is observational, no political solution is proffered or alluded to. The poem's conceit is to use two sections written in varying meters and rhyme schemes to contrast an idyllic pastoral scene ('Oh! what is so blithe as through cornfields to roam, / When the lark is in heaven and laughter on earth?' 11.1-2) with a hellish vision of the human cost of urban industrial development:

Care-stricken forms the street's long darkness fill, Embodied dreams of misery and ill!

A more than Cain-like mark their foreheads bear,

For sin's their only respite from despair!

And in each sunken eye's unhallowed cell

The fever flashes, not of life, but hell.

Oaths upon infant lips, and, loathsome sight!

The eyes of childhood without childhood's light. (11.58-65)

The moral outrage of this depiction of the human degradation caused by the urban factory system is part of a 'state of the nation' address that transfers easily across a broadly antiindustrial political spectrum; the work appealed just as easily to the largely Tory readership of the Morning Post as it did to the radical working-class audience of the Northern Star.

In contrast to Jones's occasionally transferable poetics across the political divide is the example of Mangan's 1842 translation of Lodivic-Heinrich-Christoph Hölty's 'The Grave-Digger's Chant ${ }^{\prime 8}$ :

Dig, dig my spade!

Whate'er these hands have made,

Good spade, I owe to thee! 
Rich folk and poor

Throng in at my dark door,

Come late or soon to me.

Yon yellow skull

Showed once a beautiful

But haughty brow and lip;

Yon thing of bones

Left kings and courts and thrones

For reptile fellowship! (11.1-8)

It is difficult to imagine that Mangan would have published a poem such as this which celebrates the levelling power of death after the occurrence of the Irish Famine. The poem's easy equation of 'rich folk and poor' would not have been politically acceptable after the events that began to unfold in the mid-eighteen forties. Mangan, unlike Jones, was never a political conservative whose radical conversion was the act of a renegade, but he was a writer radically interpellated by nation and history for the eventual role of 'national poet'. What, to a large extent, qualified him for this role was the poetic quality he shared with Jones: the ability to successfully invoke a mythic historical past and communicate the past's ideological relevance to the present.

By the time Mangan published arguably his most famous Gaelic translation, 'Dark Rosaleen' (1846), ${ }^{9}$ he was utilising the power of myth to engage more directly with political concerns. In the manner of the previous poem, the land is mystically personified as a beautiful female, but the character of Dark Rosaleen (Roisin Dubh) is an altogether more powerful figure than Kathaleen Ny-Houlahan, inspiring not pity but confidence and awe:

$\mathrm{O}$ ! the Erne shall run red 
With redundance of blood

The earth shall rock beneath our tread

And flames wrap hill and wood

And gun-peal, and slogan-cry,

Wake many a glen serene,

Ere you shall fade, ere you shall die,

My Dark Rosaleen! (11.73-9)

While much of the poem utilizes the sense of dislocation and yearning that traditional unrequited love lyrics express to represent the longing for a free Ireland, this stanza associates the figure of the woman with topographical land imagery. The invocation of the landscape contains a concentration of references to political unrest but the whole is incorporated into an erotic mythology built on a nation-specific archetype. Myth is used to simultaneously mask and enhance enjoined calls for political unity and action.

In some Chartist poetry action was more overtly and emphatically encouraged. Brian Maidment suggests in The Poorhouse Fugitives (1987) that threat is an important function of many Chartist lyrics beyond an attempt to 'create and extend group identity and political solidarity'. ${ }^{10}$ In Jones's Chartist work this threat is almost always directed towards the capitalist class or its perceived enablers in the Established Church or the government, but in the final stanzas of 'The Two Races'"11 it becomes apparent that the imminent triumph of the working class will demand submission or allegiance from all political classes:

But another strain is sounding,

In music fresh and clear;

And the nation's hearts are bounding, That glorious psalm to hear. 
It tells, a race has risen,

Of more than knightly worth;

Forth-breaking from its prison,

In the dungeons of the earth.

And not by lance or sabre,

These nobles hold their lands,-

But by the right of labour,

And the work of honest hands.

And not for crown and crozier,

They till the sacred sod;

But the liege-lord of their holding,

Is the lord of nature:- God. (11.89-104)

These stanzas take language traditionally associated with the aristocracy ('knightly', 'nobles', 'liege-lord') and apply it in association with the working class; a linguistic appropriation that both inverts traditional associative values ascribed to different classes, and pre-figures real social, and presumably economic, appropriation through political action. The usurpation of the dominant social position of the aristocrat by the industrialist class detailed by the early sections of the poem is now superseded by the rise of the working class - the work does not concern two 'races' but three. The poem begins to work on levels of multiple address: as an appeal to the aristocracy; as a threat to both the aristocracy and the industrialist class; and as an encouragement of the revolutionary or reformist ideals of the radical working class. The work ends with an increasing emphasis on control of the land, a divine justification for radical political action, and an invocation of natural justice: God is 'the lord of nature', the 
earth that is farmed by the workers is 'sacred', and the rise of the working class is accompanied by a 'glorious psalm'. Indeed, the implication of the final lines is that the divine right of kings has been transmuted into the divine right of the working man. The divine approval of this predicted historical phase suggests that not only is it a return to the natural state of things, but that it is to be a state of permanence. By ending the poem with the emphatic monosyllable, 'God', preceded by a heavily indicated pause, Jones suggests an unarguable finality that reinforces the association of the divinity with the workers' right to control the land which they farm. 'The Two Races' was published at the height of support in the Northern Star for Feargus O'Connor's ambitious Land Plan. ${ }^{12}$

For Mangan, even in his nationalist period, the land is more a spiritual entity than the subject of agrarian fantasy. The emphasis is less on the land's inherent usefulness than on the poetic speaker's relationship with it. When Mangan turns his characteristically oblique gaze on the Irish Famine the landscape comes to symbolize social experience. The land in his starkly evocative lyric, 'Siberia' (1846), ${ }^{13}$ is a place of alienation, desolation, and the suspension of normal sensory experience; hope is entirely absent from the poem's landscape:

In Siberia's wastes

The ice-wind's breath

Woundeth like the toothéd steel;

Lost Siberia doth reveal

Only blight and death.

Blight and death alone.

No Summer shines.

Night is interblent with Day.

In Siberia's wastes alway 
The blood blackens, the heart pines.

In Siberia's wastes

No tears are shed,

For they freeze within the brain.

Nought is felt but dullest pain,

Pain acute, yet dead;

Pain as in a dream,

When years go by

Funeral-paced, yet fugitive,

When man lives, and doth not live.

Doth not live - nor die.

In Siberia's wastes

Are sands and rocks

Nothing blooms of green or soft,

But the snow-peaks rise aloft

And the gaunt ice-blocks.

And the exile there

Is one with those;

They are part, and lie is part,

For the sands are in his heart,

And the killing snows. 
Therefore, in those wastes

None curse the Czar.

Each man's tongue is cloven by

The North Blast, that heweth nigh

With sharp scymitar.

And such doom each sees,

Till, hunger-gnawn,

And cold-slain, he at length sinks there,

Yet scarce more a corpse than ere

His last breath was drawn. (11.1-40)

The verbosity of some of Mangan's early poetry is discarded for a structure that consists of short lines (the second line of each stanza has only four syllables), and in the first half of the work, short sentences. The sense of alienation is reinforced by the first line of each stanza being set apart from the rest by playing no part in the rhyme scheme. This regular interruption of the rhyme slows down the pace but also creates the impression that each stanza is a potentially independent unit within a unified whole. Mangan's typically skilful use of repetition is more complicated in this original work than the chorus-like refrains that feature in some of his more song-like loose translations from traditional lyrics. The repeated line, 'In Siberia's wastes' begins alternate stanzas until the seventh stanza when the line, 'therefore, in those wastes' sees a gentle diminishing of the effect and signals the work's decelerating close. The first and second stanzas are linked by a syntactically altered line repetition ('Only blight and death. / Blight and death alone'), while the third and fourth stanzas are linked by repetition of the single word 'pain'. These formal diminuendos have the 
effect of smoothing out the brittleness caused by the varying metres of the lines as echoes of these repetitions create a ghostly structure in the reader's mind that reverberates through the rest of the poem. The poem's gradual letting go of these formal patterns mirrors the narrative structure as the last stanza describes a death from cold and hunger that is such a drawn-out process that the actual moment of death is almost imperceptible.

By choosing to focus on an inhabitant he describes as an 'exile' Mangan further enhances the sense of an alien landscape, highlighting the fact that many Irish people did not recognize their own land when it fell victim to famine. Although Mangan clearly signals his real subject by his use (and repetition) of the word 'blight' early in the poem, it is still something of a surprise when the political figure of the Czar makes an appearance in the seventh stanza. But if the Czar represents the British government, then this poem suggests that the effects of the famine have sapped the will of the Irish even to protest at their treatment: 'None curse the Czar. / Each man's tongue is cloven by / The North Blast'. Of course, the very fact that this poem exists (it was printed in the Nation 18 April 1846) would suggest that this is not the case, but Mangan's innate pessimism would always drive his poetry to reach for the negative. The Famine did not create Mangan's personality but converged with it. Melissa Fegan observes that 'for James Clarence Mangan, writing about the Famine was less a case of interpreting a new phenomenon, and more a recognition of his own psychic despair and sense of destiny'. ${ }^{14}$ Siberia is as much a metaphor for Mangan's own sense of melancholy and futility as for the stricken landscape of the Ireland of the Famine.

Themes of dislocation from the landscape pervade the poetry Mangan published during the Irish Famine. 'The Lovely Land', ${ }^{15}$ which describes the speaker viewing a painting of an Irish landscape by Daniel Maclise (1806-70), but thinking at first that the landscape must be Italian or French. The authorial voice's shame on realising that he is looking at a 
pictorial representation of his homeland is altogether more personal and subjective than the feelings of shame Jones hoped to induce in his English working-class readership for their relinquishment of a natural lifestyle, or their unwillingness to overthrow their oppressors:

Shame on me, my own, my sire-land,

Not to know thy soil and skies!

Shame that through Maclise's eyes

I first see thee, Ireland! (11. 33-6)

In terms of voice, the great difference between this approach to political poetry and that of Jones or most other Chartist writers is the intensely individual nature of Mangan's subjectivity. In this poem the speaker's relationship with the land is one of personal estrangement redoubled by the revelation that the land is 'first see[n]' in pictorial form. There is almost the sense that the land of Ireland cannot be viewed directly, that its perception must be mediated through cultural filters including paintings, or, in the case of 'Dark Rosaleen', love songs. Given the emotional register of these works it is possible to assume that the purpose of these mediations is at least in part analgesic. For Christopher Morash the difficulties faced by the poet writing about the Famine are due to linguistic, as well as emotional, tensions:

Famine, perhaps more than any other agent of change, forces the poet to make difficult choices; for while the sight of so many of his fellow creatures driven to the limits of existence cries out for some sort of response, famine does not sit comfortably in any of the established poetic idioms of the English tradition. Had the Great Famine taken place a half century earlier, it could have found expression in a native Gaelic tradition that embraced a long history of famine, exile and destitution. ${ }^{16}$ 
The steady decline of the Irish language throughout British rule had created a situation where middle-class or urban nationalist poets were writing in the language of their oppressors to represent a population whose peasantry was still largely Gaelic-speaking. This necessitated a hybridization of English and Irish poetic traditions that Mangan, who did not speak Irish but worked from literal translations provided by friends, embraced.

The strategy of viewing Ireland indirectly is a continuation from pre-Nationalist, early works that Mangan claimed were translated from languages including Turkish ('The Karamanian Exile' - Dublin University Magazine, 1844) and Arabic ('The Time of the Barmecides' - Dublin University Magazine, 1839, 1840). In fact, though he knew German, Mangan did not speak either of these languages, and the 'translations' were poetic hoaxes which, according to Henry J. Donaghy, used 'a mythic golden past to visualize a supposedly similar golden past of Ireland's' ${ }^{17}$ Both Mangan and Jones use their own visions of the past in order to defamiliarize the present, but Mangan occasionally adds an exoticism with his strategy of geographical, as well as temporal, dislocation:

Then youth was mine, and a fierce wild will, And an iron arm in war,

And a fleet foot high upon ISHKAR's hill,

When the watch-lights glimmered afar,

And a barb as fiery as any I know

That Khoord or Beddaween rides,

Ere my friends lay low,- long, long ago,

In the time of the Barmecides,

Ere my friends lay low,- long, long ago,

In the time of the Barmecides. (11.11-20) ${ }^{18}$ 
The first two lines of this stanza bear a striking resemblance to the first stanza of Ernest Jones's translation for the Court Journal of 'The German Boy's Song'19 by Count Friedrich Leopold von Stolberg (1750-1819):

My arm grows strong, my spirits soar!

Give me a sword to wield!

Father! Despise my youth no more;

I'm worthy of the field. (11.1-4)

This may not be a result of direct influence between the two poets; Mangan was also a translator of German literature. David Lloyd has noted that:

Mangan's translations from and articles on German literature of the late eighteenth and early nineteenth centuries constitute the greater part of his literary output. [...] The material he translated is remarkably various, ranging from the work of familiar figures such as Goethe, Schiller, Jean Paul, Novalis, and Heine to lesser known writers including Justinus Kerner, Cristoph Tiedge, and Friedrich De La Motte Fouqué. ${ }^{20}$

Mangan also translated poems by Ludwig Ühland, Friedrich Rückert and Ernst Moritz Arndt, the providers of the originals of some of the other works Jones translated for the Court Journal in the early eighteen forties. Both poets draw from their exposure to the literature of German Romanticism an association of youth with patriotic or even revolutionary fervour. The youth of Mangan's 'Kathaleen Ny-Houlahan' is reinforced by the rather curious insistence that she is 'not a ghastly hag'; Jones utilized youthful figures of visionary radicalism including the speaker of 'The Blind Boy's Song' (Northern Star 15/1/1848). Both writers employed the association between youth and a new political beginning, with its 
connotations of potentiality and lack of a corrupting memory of previous regimes and political systems.

It is tempting to see in this convergence of poetic interest between Jones and Mangan a triangulation of influence and inspiration, and indeed an interchange of mythic figures and narratives, between German Romanticism, British Chartism, and Irish nationalism in the midnineteenth century. But while the literary traffic between the German states and the British Isles might be imagined to have been largely one way (westwards, of course), there is evidence to support the contention that the interplay between the radical poetics of Britain and Ireland echoed the well-documented political discourse between Chartism and Irish nationalism at the time. It is significant with regard to Jones's engagement with Irish issues that his rise to prominence within Chartism, politically and poetically, coincided with the occurrence of the Irish Famine and the death of Daniel O'Connell (1775-1847), the leader of the Repeal Association. According to Malcolm Chase, O'Connell's death '[brought] to a close one of the most significant and turbulent careers in Irish politics but also open[ed] up a real possibility of co-operation between Irish nationalists and British Chartists'. ${ }^{21}$ In a broader sense, this co-operation would have been a continuation of a previous trend. Paul A. Pickering has noted that 'the 1842 National Petition, which had been signed by millions of working people in England, called for the repeal of the Union as well as the implementation of the Charter'.22

Chartist recognition of the plight of Ireland was reflected in poems throughout the Chartist period that depicted the Irish people as subjects of the same oppressing forces under whom the English working class suffered. Apart from acknowledged similarities between the political goals of Chartism and Irish nationalism, in terms of political context it suited Chartism for its poetry to highlight Ireland's misery. Mike Sanders writes: 
Ireland came to play an important role in the Chartist imaginary

because of the opportunity it gave to both the movement and

O'Connor to consolidate their respective identities through a dialectic

of similarity and difference. ${ }^{23}$

In some expressions of the Chartist imaginary the distinction between the identities of the two peoples, or the two movements, become deliberately blurred. William James Linton, though an English (and eventually American) Chartist poet, spoke as an Irishman for his 'Irish Harvest Song, ${ }^{24}$ which was first published in the English Republic magazine in 1851 (3467). The poem blends the familiar tropes of Chartist land poetry with an appeal for an Irish national identity and recognition of the English financial mismanagement that exacerbated the effects of the Irish Famine:

This land is ours,- God gave it us;

We will maintain our own;

This land is ours,- we will not starve

Where corn is grown;

We will not starve in harvest-time

Because some alien-born

Would speculate in corn. (1.1-7)

Long after the demise of Chartism, and probably to capitalize on the growing East Coast Irish diaspora of the time, this poem was re-published in 1867 in New York after Linton emigrated to America. It appeared in a brochure entitled Ireland for the Irish, Rhymes and Reasons against Landlordism, with a Preface on Fenianism and Republicanism.

An even more direct association between Irish and British political concerns is evidenced by Allen Davenport's 'Ireland in Chains', ${ }^{25}$ which was published in the Northern Star 25 April 1846. The poem is framed as an appeal to 'Britons' to intervene in the ongoing 
oppression of Ireland, the implication being that Ireland's suffering is a distorted mirror of Britain's own:

Rise, Britons, rise! with indignation,-

Hark! hark!! I hear the clanking chains,

That bind a brave and generous nation,

Where martial law and terror reign;

Her gallant sons demand assistance,

Can British hearts refuse the call?

Behold them struggling for existence,

Shall Ireland, or her tyrants fall?

See! see! the fiends of war

Have seized on Liberty;

Then rise, and as one man declare,

That Ireland shall be free! (11.1-12)

Written and published at the height of the Famine, this poem sees the Irish situation as a possible trigger for revolt in Britain, presenting a stark choice between the demise of Ireland or 'her tyrants'. Jones himself saw a similar link between the Irish and British political situations, and sought to forge an alliance between the working classes of both nations. Jones's 'The March of Freedom', ${ }^{26}$ celebrates the momentum of democratic revolt through successive European nations in its fifty-two quatrain stanzas, but its final stanzas are reserved for Ireland. After a refrain of 'Cry: 'Liberty to Erin!', the physical barrier of the Irish Sea is symbolically bridged by the intertwining political ambitions of Chartism and Irish nationalism:

Athwart that famous 'gulf,'

Though swift its current hies, 
We soon can build a bridge

With dead monopolies.

For hark! to Freedom's call

The fatal spell is broke;

Repeal means-Union of the slaves,

And reverence of the yoke.

Then, Hurrah for the Charter,

On Shannon, Thames, and Tweed;

Now, scythemen! to the harvest!

Reap! you who sowed the seed. (11.197-208)

Similarly, 'A Song for the People ${ }^{27}$ uses the situation in Ireland to enhance a general call for freedom and democracy. Throughout the work, the refrain 'For the world shall see - that we will be free, / And free be the sister-isle' is incorporated, indicating an apparently symbiotic relationship between the political goals of the radical elements of both nations.

At the same time as Chartist poets were incorporating Ireland into their work, Irish nationalist poets were writing radical pieces which advocated the overthrow of tyranny in general terms which would have relevance across the British Isles. John de Jean Frazer, an Irish nationalist poet known pseudonymously as 'Jean de Jean', published a collection called Poems for the People (Dublin: Browne, 1845) which included the poem, 'A Word to the People'. ${ }^{28}$ This poem, with its plea for solidarity amongst the oppressed, speculation of a future of liberty, and connotations of divine approval of radicalism in the term "anointed", could easily be read as a Chartist text:

Oh! could we thus in concord live, 
As brother should with brother;

And, with no sordid feelings, give

Our efforts to each other:

With hands so strong, and hearts so firm,

By freedom's cause anointed,

How soon would be a stinted term

To tyranny appointed! (11.9-16)

In the aftermath of the Irish Famine, as ruling classes across Europe fell to popular revolt, the same poet published a work called 'Harvest Pledge'29 in the Nation issue of 8 July 1848 three weeks before the paper was seized and suppressed by the authorities for over a year. The manner of this work was distinctly more threatening than that of 'A Word to the People', and its language provides the perfect Irish analogue to Ernest Jones's brand of radical poetic medievalism:

So the serfs, in the face of the Lord of the Manor

Set a spear for a shaft and a sheaf for a banner;

And said, 'If we choose, from the sward to the sky,

From centre to shore, thou shouldst yield - or die!' (11.13-6)

Despite the occasional despondency that Mangan's nationalist poetry retained from his earlier period, his work could contain distinct elements of threat, as 'Dark Rosaleen' shows. The work which helped to consolidate his status as national poet, 'Irish National Hymn', ${ }^{30}$ published in the United Irishman 13 May 1848, carries relatively explicit threats alongside familiar references to divine justification and a feminising celebration of the Irish landscape:

Strong in thy self-reliance,

Not in idle threat or boast,

Hast thou hurled thy fierce defiance 
At the haughty Saxon host -

Thou hast claimed, in sight

Of high Heaven, thy long-lost right.

Upon thy hills - along thy plains -

In the green bosom of thy valley,

The new-born soul of holy freedom rallies,

And calls on thee to trample down to dust thy chains! (11.21-30)

This stanza's insistence on 'self-reliance' as a pre-requisite for national independence recalls Thomas Davis's poem of that name, ${ }^{31}$ which entreats its readers not to 'hide your chains in pleasures garlands'. However, where Davis popularized the ballad as an Irish nationalist poetic form, Mangan's work takes the form of a radical hymn, a form which would have been more than familiar to English readers of Chartist poetry. Ernest Jones published a series of three radical hymns for publication in the Red Republican journal on his release from prison in $1850 .^{32}$ The singing of radical hymns at Chartist meetings was such a popular practice that there are several references to Chartist hymn books in the Northern Star. The only known surviving example of this form of publication was discovered in Todmorden Library in West Yorkshire in 2009. ${ }^{33}$

The new-found political consciousness that infused the poetry of Jones and Mangan from 1846 was transformative as much in its effects on the reception of their work as on the production. Radicalism consolidated and gave focus to their particular mythopoeic visions but the sense of a receptive readership, and a narrowed poetic address towards that readership, fed back into their work and gave it a purpose and function hitherto absent. The important shift was that through the organs of the Northern Star and the Nation both poets became public property, radical laureates for political movements desperately in need of heroes. The association of poetry and literature with higher forms of culture necessitated the 
recognition of legitimising representatives within Chartism and Irish nationalism. If these movements were to prove their fitness as viable alternatives to the status quo they had to mirror the cultural spectra of the established societal structures they set themselves up against. Jones and Mangan found themselves best placed to fulfil roles that would only have been taken by other poets had they not been there.

In terms of content and register, Jones's poetry displays more directness, more overt political muscularity, than Mangan's. He is, perhaps, the less subtle writer. But it could be argued that for a political movement with a pre-existing political aesthetic and an ostensibly single, easily definable function (the attainment of the vote for the working man), such directness was appropriate. Jones wrote for a very wide and varied readership and, in terms of literariness and even literacy, he had to take account of the lowest common denominator. Mangan's case was more complicated on both counts. The Irish Famine re-focused nationalism and created in Irish poetry a sense of urgency and almost hallucinogenic disbelief: Mangan's poetry became more relevant precisely because of its dark colours and occasional semantic opacity. In terms of readership, Mangan was writing for a smaller, more literate audience for whom the Irish Famine and its attendant trends of mass emigration precipitated the need for increased efforts to establish a solid national identity.

The separate causes of occupation and industrial urbanization produced similar recognitions and representations of geographical dislocation in the poetry of Jones and Mangan. The audiences they wrote for, and to, were similarly alienated from what was perceived as their birthright. Both poets drew on rich storehouses of mythic national history to invoke a radical nostalgia that was conversely conservative in its essential nature: a more just future necessitated a form of return to the past. Adapting examples partly provided by their shared influence of patriotic German Romantic poetry, Jones and Mangan presented visions of histories that were cyclical, recoverable, and existed to justify present political 
action. But beyond immediate political goals, the poetry of these writers reflected the ultimate ambition of both Irish nationalism and Chartism: the creation of cultural identities worthy of the political self-determination they respectively sought. 


\section{Notes}

${ }^{1}$ Jones, Ernest, 'Preface', The Labourer: A Monthly Magazine of Politics, Literature, Poetry etc. Vol. 1. Ed. by Feargus O'Connor and Ernest Jones (London: M'Gowan, 1847), p.1.

${ }^{2}$ Welch, Robert, A History of Verse Translation from the Irish 1789-1897 (Gerards Cross: Smythe, 1988), p.108.

${ }^{3}$ Jones, 'Echoes No.I: The Golden Harp', Morning Post 19/1/1844.

${ }^{4}$ Anne Janowitz makes reference to the second poem in the 'Echoes' series, 'The Cornfield and the Factory', in Lyric and Labour in the Romantic Tradition (Cambridge: Cambridge University Press, 1998, p.177), but only identifies it as a stand-alone poem republished in the Northern Star in June 1846.

${ }^{5}$ Mangan, James Clarence, 'Kathaleen Ny-Houlahan', The Collected Works of James Clarence Mangan Vol. II, 1838-1844, ed. by Jacques Chuto, Rudolf Patrick Holzaphel, Peter Mac Mahon, and Ellen Shannon-Mangan (Dublin: Irish Academic Press, 1996), p.23940.

${ }^{6}$ Donaghy, Henry J., James Clarence Mangan (New York: Twayne, 1974), p.82.

${ }^{7}$ Jones, 'Echoes No. II: The Cornfield and the Factory’, Morning Post 20/1/1844.

${ }^{8}$ Mangan, 'The Grave-digger's Chant', Collected Works Vol. II, 1838-1844, p.289.

${ }^{9}$ Mangan, 'Dark Rosaleen', Collected Works Vol. III, 1845-1847, p.169-70.

${ }^{10}$ Maidment, Brian, The Poorhouse Fugitives: Self-taught poets and poetry in Victorian Britain (Manchester: Carcanet, 1987), p.37.

${ }^{11}$ Jones, 'The Two Races', Northern Star, 12/9/46.

${ }^{12}$ The Chartist Land Plan was intended to provide viable agricultural plots and residences for urban workers through a subscription scheme. Much of the pastoral vision of Jones's early Chartist poetry is informed by the Land Plan's policy to return urban workers to the perceived smallholding traditions of their forefathers. 
${ }^{13}$ Mangan, 'Siberia', Collected Works, Vol. III, 1845-1847, p.158.

${ }^{14}$ Fegan, Melissa, Literature and the Irish Famine 1845-1912, (Oxford: Clarendon, 2002), p.169.

${ }^{15}$ Mangan, 'The Lovely Land', Nation 18/7/1846.

${ }^{16}$ Morash, Christopher, ed. The Hungry Voice: The Poetry of the Irish Famine (Dublin: Irish Academic Press, 1989), p.18.

${ }^{17}$ Donaghy, p.35.

${ }^{18}$ Mangan, 'The Time of the Barmecides', Collected Works, Vol. II, 1838-1844, p.169.

${ }^{19}$ Jones, ‘The German Boy’s Song', translated from Count Friedrich Leopold von Stolberg.

Cutting from The Court Journal (no date), Ernest Jones Manuscript Poems, Manchester County Record Office, MS. f281.89 J5/95.

${ }^{20}$ Lloyd, David, Nationalism and Minor Literature: James Clarence Mangan and the Emergence of Irish Cultural Nationalism (Berkeley: University of California Press, 1987), p.129.

${ }^{21}$ Chase, Malcolm, Chartism: A New History, (Manchester: Manchester University Press, 2007), p.271.

${ }^{22}$ Pickering, Paul A., “Repeal and the Suffrage': Feargus O’Connor's Irish 'Mission', 184950', The Chartist Legacy, ed. by Owen Ashton, Robert Fryson and Stephen Roberts (Rendlesham: Merlin, 1999), p.119-46, p.119.

${ }^{23}$ Sanders, Mike, The Poetry of Chartism: Aesthetics, Politics, History (Cambridge: Cambridge University Press, 2009), p.132.

${ }^{24}$ Linton, William James, 'Irish Harvest Song', An Anthology of Chartist Literature, ed. by Y. V. Kovalev (Moscow: Foreign Languages Publishing House, 1956), p.201.

${ }^{25}$ Davenport, Allen, 'Ireland in Chains', An Anthology of Chartist Literature, p.123.

${ }^{26}$ Jones, 'The March of Freedom' Northern Star 18/3/1848. 
${ }^{27}$ Jones, 'A Song for the People', Northern Star 4/3/1848.

${ }^{28}$ Frazer, John de Jean, 'A Word to the People', Political Verse and Song from Britain and Ireland, ed. by Mary Ashraf (London: Lawrence, 1975), p.190. It is worth speculating that Jones's 1851-2 Notes to the People journal series took its directly demotic name in part from Frazer's collection, Poems for the People. Jones's interest in Irish nationalist literature predated his involvement with Chartism and he was likely to have been familiar with Frazer's work.

${ }^{29}$ Frazer, 'Harvest Pledge' Nation 8/7/1848.

${ }^{30}$ Mangan, 'Irish National Hymn', Collected Works, Vol. IV, 1848-1912, p.48-9.

${ }^{31}$ Davis, Thomas, 'Self-reliance', National and Historical Ballads, Songs, and Poems, ed. by Thomas Wallis (Dublin: Duffy, 1874) p.8.

${ }^{32}$ The three hymns were published in the Red Republican in consecutive weekly issues: 'Hymn for Ascension Day’ (20/7/1850); 'Hymn for Lammas Day' (27/7/1850); 'Easter Hymn' (3/8/1850).

${ }^{33}$ A copy of the National Chartist Hymn Book can be viewed at http://www.calderdale.gov.uk/wtw/search/controlservlet?PageId=Detail\&DocId=102253\&Pa geNo=1 
